\title{
CONDITIONS OF CHANGE: THE REGIONAL ROLE OF A ROMANIAN AGRICULTURAL SECONDARY SCHOOL
}

\author{
Zoltán Biró A. - ÁGNES SÁROSI-BLÁGA - KINGA KATALIN SZÉKELY ${ }^{1}$
}

\begin{abstract}
The focus of our study is a high school with an agricultural education programme operating in a rural micro-region within Harghita County (Romania), in which context the relationship between the school and the regional society comes under analysis. Since the 1970s, it has been the school's mission to provide the micro-region's professionals with a secondary education, and today it still intends to maintain this micro-regional function. It has been struggling with significant operational and maintenance problems for several years now, while the evolution of its micro-regional role is uncertain. The present study puts under scrutiny the attitude of parents and the region's élites towards the school and its regional role as well as analyses the school's service-marketing practices towards the region. The aim of the study is to analyse the school-community relationship and the school's marketing communication. The main research question is: what is the regional role of the school and how can it be strengthened? Analytical results indicate that repositioning the regional role of the school seems to offer a way out and a development opportunity for the institution.
\end{abstract}

KEYWORDS: agricultural secondary school, rural development, parents, rural élites, marketing communication

1 Zoltán Biró A. is professor at Sapientia Hungarian University of Transylvania, Cluj-Napoca, Romania; email address: biroa_zoltan@yahoo.com. Ágnes Sárosi-Blága is PhD candidate, sociologist at WAC - Center for Regional and Anthropological Research, Miercurea Ciuc, Romania; email address: kamintezet@yahoo.com. Kinga Katalin Székely is assistant professor at Sapientia Hungarian University of Transylvania, Cluj-Napoca, Romania; email address: kingaszekely@ gmail.com. 


\section{INTRODUCTION}

The twenty-first century has brought about a substantially transformed role and operational model for schools. The specificities of these changes can be highly diverse depending on the social context and educational levels, but the need and necessity of operating according to a business model has definitely taken on priority status in the operation of schools (see Fulton 2003; Pollit 2003; Santiago et al. 2005). The literature on the subject suggests the application of specific methods; first of all an emphasis on strategic thinking as well as the possibilities and tools of school marketing (e.g. Sousa 2013; White-Reid 2008; Hutflesz 2004; Muhi 2012). According to Sousa (2013: 177-178), communication, including the communication between schools and parents, is an essential tool for the strategic management of educational institutions. The strengthening of communication is very important in reconstructing the collective identity of an educational institution, in parents' perceptions about schools, and in cooperation between teachers, students, and families (Sousa 2013: 178).

The issues around the rural development role of schools that operate in rural areas have found a place on the agenda of professional discourses in Romania too (Biriescu-Babaita 2014). The authors of the present work, however, claim that developing such a role requires complementary efforts that include, inter alia, increasing the capacity of rural institutions, infrastructure development, establishing supportive policy frameworks, etc. (Biriescu-Babaita 2014: 77-78). In the author's view, operating in accordance with a business model is a difficult mission for schools as there are no historical traditions in this regard, and the latter also have inadequate professional knowledge. Experience has shown that the management bodies of institutions operating in rural areas have reservations concerning marketing processes, while also having little knowledge of them (Sárosi-Blága 2018a, 2018b).

The above-listed challenges become even more formidable for technical schools operating in rural areas because these are lagging behind in multiple development-related aspects compared to the average, while at the same time they need to take certain factors into consideration - such as changes in the popularity of the professions taught in these schools or the emergence of new training needs connected with agricultural innovation processes. All this clearly points to the fact that the future of high schools operating in rural areas is not merely an educational issue but an essential regional development matter as well. In order for - for example - a technical college operating in a rural area to be able to take advantage of the potential inherent in a possible regional status, the school should consider changing its position towards the region and try to reposition itself in relation to the current regional realities. 
There are several agricultural technical colleges operating in the Szeklerland area but with a moderate role at the regional level. In recent years, agriculture has undergone several changes in this region: the number of innovative agricultural initiatives has dramatically increased, and new actors and business models have emerged in the area (Biró-Magyar 2013, 2016, 2017, 2018, 2019). Based on our previous observations and field experience, agricultural technical colleges in the region have played a minor role so far and have not got involved in the transition processes. A network of relations and cooperation has not been established between the school and the regional society. The high school analysed in our study was founded in a rural environment in the year 1961, and starting with the 1970s its mission has been to train agricultural professionals for the microregion. Ever since, it has endeavoured to adhere to this commitment; however, it has been struggling with operational problems for a number of years now. Based on a complex piece of school-related research carried out in 2017 (we addressed questionnaires to parents and key actors of the region, and we analysed the school's communication activity), we examined three factors that play a decisive role in the life of a typical rural technical college in terms of the changing relationships between the school and the regional society, and that are essential should the educational institution attempt to reposition its regional role. The three analysed areas are as follows: (a) parents' attitudes, (b) the regional élites' attitude, and (c) the operation of the school according to service-marketing criteria.

The analysis of the school's marketing communication is a general one, and there is reason to ask how adequate the business model approach is for schools. We believe that if there is an intention to establish a cooperation model that serves the relationship between the schools and the surrounding social environment, then the former should reposition themselves, and an analysis based on marketing tools can be of assistance in ferreting out the procedures appropriate for this purpose.

\section{ASPECTS OF LITERATURE}

The twenty-first century changes in the role of schools require the consideration of new factors regarding both the operation of these institutions and the related professional thinking. In connection with the economic principles and needs that are becoming increasingly emphasized in the operation of schools, adaptation is a crucial issue of competitiveness, meaning the adoption of solutions and operational models that result in the long-term sustainability of schools. 
Regarding the adaptation of schools to the new realities, the literature discusses several aspects. The primary focus of our study is on literature approaches that deal with economic aspects of the adaptation to twenty-first-century changes (e.g. Fulton 2003; Pollitt 2003; Santiago et al. 2005) as well as with the dangers of liberal thinking (Gewirtz et al. 1995; Woods et al. 1998; Burch 2009), while also raising awareness of the importance of transforming organizational culture as a practical solution (Gewirtz et al. 1995). The latter is closely linked to the issues associated with the social embeddedness of schools, which, in relation to school managements, implies consideration of certain factors such as the possibility of developing a marketing concept (e.g. Sousa 2013), the harmonization of market requirements with the pedagogical discourse, the organizations' bureaucratic mode of operation (Sousa 2013), the importance of collective identity, and reinforcing the social image of school within the family environment (Lipman 2011).

Sousa (2013) draws attention to the fact that a considerable proportion of authors and references that discuss economic aspects in the changing role of schools (e.g. Fulton 2003, Pollitt 2003, Santiago et al. 2005) understand the field of education in accordance with the characteristics of the economic market, whereby educational actors are considered nothing more than consumers, clients/customers, and managers. These studies treat issues such as the measurable success and competitiveness or the management characteristics of schools as a public service organization in the general sense (e.g. Pollitt 2003). Some authors suggest that this paradigm shift might endanger natural selection and thus contribute to the reproduction of social inequalities. Although the authors and works cited herein touch upon the risks of new ideologies associated with the operation of schools in a context different from our research field, we consider it important to mention a few of them. As postulated by Gewirtz, Ball, and Bowe (1995), understanding education based on market considerations sees parents' choice as a key factor. Taking a closer look at parents' choices and options, the referred-to authors call attention to the considerable discrepancies between the patterns of access and participation (involvement) depending on, for instance, gender, ethnic affiliation, and social class. Woods, Bagley, and Glatter's (1998) study calls attention to the same point, analysing the criteria parents find relevant when opting for a specific school. Burch (2009) claims that by transferring education management from the public to the private sector in the United States new social inequalities have become institutionalized and old ones reinforced - however, discussing the dangers posed by economic aspects extends beyond the ambitions of the present study.

In what follows, we would like to highlight certain approaches found in the literature that consider social-embeddedness issues as essential elements when 
addressing the twenty-first-century challenges that schools are presently facing. In our case, the concept of social embeddedness covers certain factors related to organizational culture and school management, such as communication or the social image of schools. In Sousa's (2013) view, establishing the collective identity of schools is a vital element in strategic planning, not just in terms of organizational communication but also regarding the positioning of schools. The author formerly cited weighs in with reference to the Portuguese context, wherein he argues for the importance of communication as a school management tool, which he defines first of all through the relationship between schools and parents. In his opinion, strengthening communication with parents and other groups of stakeholders may increase the social prestige of schools as well as social participation. Competitive constraints that can be experienced in relation to the education market are not the sole reason why the social positioning and embeddedness of schools that is taking place via strengthening communication deserves attention (Hutflesz 2004; Muhi 2012; White-Reid 2008), but community development considerations should be borne in mind as well (Miller 1995). This newly defined role of the school makes it necessary to establish partnerships between rural schools and local communities, and it is tightly connected with the development opportunities of rural areas (e.g. Wallin-Newton 2014; Lingam et al. 2014; Bauch 2001; Olsen 2017).

Miller's model (1995) for reimagining the role of schools suggests approaches that can tighten the relationship between schools and their communities. We believe these suggestions can not only be utilized on the local scale, but with respect to rural micro-regions consisting of several settlements, with centres giving a home to high schools that serve all pertaining settlements, which could also benefit from them. The suggested approaches aim at diminishing or eliminating the boundaries that traditionally separate schools from communities. With the proposed solutions, they wish to achieve that schools and communities work together for mutual benefit. The first approach sees the school as a community centre that provides both wide-ranging services and resources for lifelong learning. This way, school resources (building, technology, and staff) can be used to offer training and retraining opportunities to community members (Miller 1995: 166). The second approach emphasizes the necessity of conducting sociological surveys in order to increase students' appreciation for their immediate environment and the community they are part of. It is essential that students study their community by assessing needs, observing environmental and land-use particularities, and documenting local history with the help of interviews and photos. The third approach argues for the importance of a school-based enterprise with the main focus on acquiring entrepreneurial skills that meet community requirements and on creating new enterprises. 
The above-mentioned approaches are of immense significance in the region under study, also because there is traditionally a significant gap between schools and communities in these settlements. Being familiar with the socio-historical processes in the region, it can be stated that schools have not formed part of the community's social capital - and not even after the 1989 regime change in Romania did they become part of the local development process. They never adopted an approach according to which schools should also be considered as embedded into the three pivotal and inter-conditional components of social capital (symbolic diversity, resource mobilization, and quality of linkage; see: Flora-Flora (1993)), this way enabling such institutions to become major players in local development (Miller 1995: 164).

\section{THE ANALYSED SCHOOL AND THE MICRO-REGION}

The post-1989 education system in Romania is characterized by frequent and contradictory changes affecting the legal and administrative framework. First of all, academic high schools operating in cities were the ones to benefit from infrastructure-related as well as didactic and pedagogical development opportunities, followed by technical colleges that managed to establish cooperative relations with major industrial enterprises. High schools operating in rural areas were left out of these development processes. This is also explained by the fact that "Romanian rural area[s] and [their] problems [are not] prime [...] legislative, administrative, political and economic [planning concerns] in Romania, even more, some failures are largely ignored or are approached inadequate[ly]" (Biriescu-Babaita 2014: 80).

A further essential feature is that secondary vocational training has been negatively affected on several levels: due to the large-scale restructuring of the economic and labour market system in Romania and the boom in university education that enhanced the value of academic high schools, apprenticeship training was suspended for several years. Situated on the periphery of secondary vocational training, rural high schools became the biggest losers of the network of secondary education institutions. This is clearly illustrated by the fact that only a small number of graduates from these schools are able to meet the requirements of the final examination (Matura). It is a new development that central authorities are planning on reducing enrolment quotas for high schools that produce unsatisfactory baccalaureate examination results. Considering the above-described situation, it is expected that high schools operating in rural settlements will have to choose between a deeper embeddedness in regional 
society or closure. The school studied in our paper is a typical example of an institution in such a difficult situation, facing tough choices. Professional analyses in Romania (Tomoletiu-Moraru 2010) also call attention to the necessity of increased social embeddedness, highlighting the importance of schools' integration into the community as well as enhancing the links between schools and their local community.

The school under analysis was established in the year 1961 and it operated as an institution for theoretical knowledge instruction until the mid-1970s. The number of graduates was around 30 each year, with a fairly good rate of progress to further education (technical schools, university education). This period marked the golden age in the school's history, when the institution operated as a regional-scale intellectual and educational centre. Starting from the year 1977, subsequent upon the centrally imposed reorientation of the education programme on repeated occasions, the institution operated as an agro-industrial high school that witnessed an increasing number of students. Upon completion of compulsory schooling (grade 10), students would receive vocational qualification as stock breeders or mechanics. From this time on, its task set out in accordance with central planning was to provide the socialist agriculture of a given rural micro-region with a workforce with a secondary education and to prioritize vocational training over theoretical knowledge instruction.

Subsequent to the 1989 regime change in Romania, the school management made an attempt to restore the operational model of the initial period marked as the golden age of the school. In 1991, the institution adopted the name 'academic high school', and major attention was paid to strengthening institutional identity (the institution was named after the most prominent poet in Hungarian literature). Nevertheless, the transformation of the regional secondary education network, the economic restructuring on the regional level, the improved attractiveness of the county centre, changes in social attitudes towards education, and other factors imposed certain restrictions on the institutional rehabilitation process, making this high school operating in a rural environment gradually lose its appeal, which process is ongoing even today. Engagement in the training of professionals on the regional level is what the school considers its specific role once again; it has relaunched its agricultural education programme, recruits its students from the micro-region; and specifically links training content to agriculture and regional development.

Nowadays, kindergarten children, elementary schoolers, grade schoolers, high school and technical school students study at the institution (350 on average), 140-150 students participate in secondary education (three- and four-year training programmes), the number of graduates from the fouryear education programme ranges between 20 and 30, and the proportion of 
successful graduates is extremely small - similarly to other schools operating in rural environments. The range of the four-year training programmes offering a baccalaureate diploma includes agrotourism, general tourism, and economics, whereas the three-year vocational education programme provides qualifications in agrotourism and mountain farming. The entire school staff is 50 strong, of which the educational staff consists of 40 persons. Nearly half of the students in the four-year education programme are members of the local community, while the rest of them come from nearby settlements. All regional settlements are almost equally represented in the school's apprenticeship programme. The school is an entirely state-funded institution. The institution lacks teaching apparatus as well as the agricultural machinery that would be required by the nature of the vocational training, and an experimental farm has not been established to date. Students studying in the institution undertake apprenticeship training at enterprises operating in the region.

The school's attraction zone includes 15 larger rural settlements and a few small settlements - this micro-region forms part of the central area of Harghita County (Romania) in the so-called Ciuc Basin. The number of inhabitants slightly exceeds 40,000 and the population of all but two of the settlements is made up of ethnic Hungarians. The area under analysis experienced a slight drop in population subsequent to the regime change in Romania, but since the population decline has been below $10 \%$ the school system in the region has not changed in any substantial way. The principal sectors of economic activity in the region are as follows: agriculture, forest and timber harvesting, food industry, and tourism. The traditional family-farming model is typical of more than half of the households in the region. The local employment rate is not significant: part of the active population works in a nearby county centre, others are employed abroad, and self-employment connected with family farming is significant. Utilized agricultural areas (meadows, pastures, and arable lands) constitute $65 \%$ of the total, with pastures and meadows playing a more pronounced role (livestock farming). The percentage of landowning households that undertake some sort of farming activity in addition is close to $80 \%$. The overwhelming majority of households are engaged in familyscale farming, this way creating a payment instrument (Laki-Biró 2001). The past decade has seen the emergence of small-scale innovative agricultural innovation in this region too, whose primary concern is making the most of the endogenous conditions (local products), and these target the regional market. With reference to the micro-regional context, we must also point out the fact that the examined micro-region forms part of an area in Szeklerland that is inhabited by a compact Hungarian population, while the school is part of the Hungarian-language educational network in Romania. 


\section{RESEARCH METHODS}

The analyses presented in our study are part of a complex piece of school-related research carried out in 2017, in the course of which we examined the situation and operation of a high school with an agricultural education programme. The research programme was encouraged and supported by Kistérségi Társulás (Micro-Regional Association) that was operating in the area. In connection with the above-described research programme, our study introduces three modules of the situation analysis. In the first module, we examined our target population by means of a questionnaire ( $\mathrm{N}=188)$, contacting the group of parents whose children were students at the school during the research period. At the time of the survey, parents of all students at the school received our questionnaire. The self-administered questionnaire contained questions covering six topics related to the operation and regional role of the institution: (1) the regional role of the institution; (2) public perceptions about agricultural instruction; (3) the content of agricultural training; (4) the strengths of the institution; (5) disadvantages and barriers to the operation of the school; and (6) the development of the school. Answers could be given on a five-point Likert scale.

Similar topics and methods were used when asking the intellectual élite: key actors (heads of institutions, teachers, doctors, priests) of the local institutions $(\mathrm{N}=120)$ in the settlements of the micro-region. In the second analytical module of our study, two sets of questions included in the questionnaire filled in by the élites received special attention: the general perception of agricultural instruction and the present as well as future regional role of the school.

In the third analytical module we examined the marketing activities of the school, with a particular focus on the fourth component of the marketing mix, promotion (Kotler-Fox 1995). According to the approach adopted by several authors (Fazekas-Harsányi 2011; Horváth-Bauer 2013), marketing communication tools may be divided into ATL (Above The Line) and BTL (Below The Line) groups. Communication tools 'above the line' are identified as using traditional advertising tools (newspaper, TV, radio, cinema advertising), while those 'below the line' are characterized by a broader set of tools (SP-sales promotion, POP-POS - point of sell, point of purchase communication tools, event marketing, trade fairs, exhibitions, sponsorship, direct marketing, etc.).

The combination of marketing services offers a comprehensive view of how the institution defines and positions itself and its scope of activities with respect to the regional community that represents its attraction zone, and provides us with information about the school's marketing communication aspects.

The results of the three analytical modules make it possible to explore the relationship between the parents and the regional élite with the school, and its 
regional role on the one hand and the extent to which the institution's marketing communication activity is directed towards the institution's social environment on the other.

\section{RESULTS AND DISCUSSION}

\section{Parents' attitude}

The social perception of the approach to the agricultural sector in the studied region has partly changed during the past three decades. The family land tenure system as well as family-scale farming practices have remained stable elements. After the introduction of land-based subsidies, this position was consolidated even further. The favouring of agricultural innovation initiatives and local products and the emergence of community organizations have brought about positive changes. All of this may also have contributed to the fact that partly in terms of livelihood and partly in terms of employment the agricultural sector has remained important among the regional population to the present day. This attitude manifests itself in parents' answers as well: $57 \%$ of the respondents totally agree and $20 \%$ agree with the statement that the agricultural sector will continue to be important for a long time, while those who disagree represent only $10 \%$.

We found similarly strong positive attitudes in relation to three further topics associated with various subdivisions of the agricultural sector. Respondents were of the opinion that the regional development of agriculture is also important because it can be linked with environment protection and the appreciation of nature. This is considered extremely important by $62 \%$ and important by $20 \%$ of the respondents. A few percentage points lower but still similar opinions were reported in response to the question whether the dissemination and application of new knowledge and new technologies are seen as necessary in the agricultural sector. The positive perception of innovation and modernization was not previously characteristic of this region.

At the same time, commitment to the agricultural sector is also illustrated by the fact that respondents particularly advocate the perpetuation of certain elements pertaining to the earlier farming model typical of the region that were eliminated by centralized socialist agriculture and which farming families in the region have been trying to rehabilitate following the 1989 regime change in Romania. These farming traditions in the region under investigation constitute the fundamental components of the operational 
model of backyard farms - some typical examples being attachment to land ownership, working towards subsistence and holistic farming, and part-time or full-time self-employment. According to our research data, three-quarters of those in the group of parents consider it either important or extremely important that the traditional farming model be continued but in a more modern way.

Positive attitudes connected with how the role and future of regional agriculture is seen may provide a supportive context for assessing the present and future situation of the agricultural high school as well. If in most of the cases parents take a positive view of the situation regarding agriculture in the region, then this positive perception can indirectly justify the existence of the school and its professional role in the region. The interconnection of regional agriculture and the perception of the school is also indicated by the fact that slightly more than half of the respondents totally agreed that the school provides opportunities for its students to become farmers or agricultural entrepreneurs after completion of their training, and an additional nearly one-quarter of respondents agreed with this proposition.

Certainly, we cannot claim that parents are of the same opinion as those of regional society. However, it should be pointed out that the major role played by community knowledge is still typical of the rural settlements in the region; this way, local public perception is integrated into how the agricultural sector is perceived and how schools are chosen. There are reasonable grounds to believe that the above-described pattern of parental attitudes shows significant overlap with the pattern of local community attitudes.

During the process of data collection, we also asked directly how parents see the school's role in the region and to what extent they agree that the school could function as the base of agricultural training in the region. Almost all of the respondents (94\%) are of the opinion that the school has played an important role in the region so far, and it should fulfil this role in the future too. The share of those opposing this view is as small as $1.5 \%$. This high support rate is important because a significant part of the parents do not live in the same settlement as the school is located in, and symbolic rivalry - sometimes even conflict - between the different settlements is traditionally fierce. It seems that the regional perception of the school extends beyond this traditional regional pattern of behaviour. The importance of the particular regional role of the school is also indicated by the fact that according to $83 \%$ of the respondents, the agricultural profile of the education institution is the most pivotal element, and it should be further enhanced. The direct question as to whether this school should serve as the basis for agricultural training in the region yielded $78.3 \%$ straightforward 'yes' answers. 
Public awareness directed towards the situation and operation of the school is illustrated by the fact that respondents hold strong opinions as to what could be further important modalities of institution-building. With a view to furthering development, $87 \%$ of the respondents emphasized collaboration between the settlements; three-quarters of them consider it essential to cooperate with the university that operates in the nearby county town, while $80 \%$ find it important that the institution integrates adult education programmes and specific training courses, too, into its activities. Integrating new services and activities into the institution's operation as well as harnessing the potential that lies in the institutional ties within the region can be seen as acceptance and social support for the regional role played by the school.

To sum up the parents' opinions, it can be stated that they have confidence in the key role of the agricultural sector, and a vast majority of them take the view that students who enrol in this school will be able to succeed as farmers or entrepreneurs in the sector in question. The agricultural sector is looked upon as something that is connected with the traditional models in the region but one that also favours innovation.

An overwhelming proportion of the respondents recognize and appreciate the past and future role of the school in vocational training, and there is a high level of consensus that this school - with the help of further improvements - can function as the basis for agricultural training in the region. Parents' opinions indicate significant potential social support for the institution.

\section{The attitude of regional élites}

Within the framework of data collection, we asked those persons with postsecondary qualifications that live in the attraction zone of the school and work as heads of institutions or have jobs that require tertiary qualification (pedagogues, officials, agricultural professionals, and others). It can be assumed in the case of this group that its members are also concerned about the situation of the region as a whole, follow the regional processes with attention, and have their own opinions about the latter.

Nearly $90 \%$ of the respondents consider the presence of agriculture in this region as important or extremely important and have ideas regarding the future of this sector. This is a much higher percentage than we recorded in the case of parents. We obtained even higher values when asking about the importance of innovation associated with the agricultural sector. Opening up access to innovative professional knowledge and technologies is considered as important by $23.3 \%$ of the respondents and as extremely important by $71.7 \%$ of them. 
This high support rate is in line with the finding that $93 \%$ of the regional élites attach to the key role played by agriculture in the region the importance of environment protection and appreciation of nature as well. The high level of commitment to the agricultural sector in the region is a relevant indicator also because it points to a regional-level change in perceptions. In the region under study, members of the élite have traditionally been attached to local-scale realities; in particular to the local identity structure, whereas the deepening of regional-scale engagement is a new development, which can be theoretically utilized by the technical college engaged in agricultural training.

Although in a somewhat lesser proportions, additional supporting views were expressed according to which the agricultural development of the region should take into consideration the farming models developed in the course of the social history of the region - the modernization of this sector should pay attention to these traditional patterns as well. Two-thirds of the respondents found this an extremely important issue, $15 \%$ of them answered that it is important, with the rest of them being uncertain in this regard, and there was a very small proportion of negative responses. The regional élites share the view of the parents that agricultural education in the region can provide an opportunity for students to become farmers and agricultural entrepreneurs in this region. The majority of the respondents $(81 \%)$ share this view.

Eight-five percent of the respondents are of the view that the school has been playing a key role in the region so far, and this role should be carried on and reinforced in the future. This regional role is specifically linked to operating the agricultural education programme, including the following specializations: agrotourism, general tourism, and mountain farming. The operation and development of the agricultural education programme is of evident importance in the eyes of $96.7 \%$ of the regional élite. A slightly smaller percentage (90\%) of respondents are in favour of this institution serving as the basis for agricultural training in the region. In their opinion, this requires expanding the existing functions and areas of activity as well as involving both intra- and extra-regional resources. In the context of diversifying the areas of activity, the integration of adult education programmes could be a useful step forward. Regional and local resources alike are considered important elements in the development process. Less than half of the respondents expressed the view that moving forward would only be possible with central (government) support. Instead, the emphasis is placed (by $90 \%$ of the respondents) on the orchestrated efforts of the municipalities found in the catchment area of the school.

Summarizing the results of the analysis creates the picture that the vast majority of regional élites see agriculture as a key sector and are in favour of innovation based on knowledge development and local traditions. They 
recognize the importance of the school's regional role so far and agree that this regional role should be carried on so that the school under analysis can become the basis for agricultural training in the region. Moving forward also implies diversification of the school's fields of activity. Therefore, it needs to rely to a great extent on the regional cooperation and relations system (pooling of efforts between municipalities) as well as on its connection with the university operating in the area. We can conclude that the overwhelming majority of the regional élites takes a positive approach to the technical college under investigation and its regional role, and the strength of this positive attitude is far greater than experienced among the parents, while it is closely linked to the élites' opinion that the agricultural sector plays a very important part within the region, which is expected to be maintained in the future too.

\section{The school's marketing communication}

School's communication activities were examined with a particular focus on the fourth component of the marketing mix - promotion (see Kotler-Fox 1995).

In the context of promotion, traditional ATL (Above The Line) and nontraditional, more customized BTL (Below The Line) marketing tools are equally involved. A member of the teaching staff is nominated as responsible for the school's marketing activities, without a larger strategic framework. At the time of the analysis, a teacher who teaches economics was carrying out these activities, with the help of a team of students organised by him.

The school has recourse to advertising in the media only once a year, when it publishes the enrolment quotas of the following academic year and the names of the specializations to be launched next year for the future ninth-graders. Apart from that, presence in the media occurs on an ad hoc basis: if a major or unusual school event draws the attention of the regional journalists, only then is a press release published about the institution. Appearances on regional radio or television are highly infrequent and random. The school does not create audiovisual materials, public-space advertisements, or infographics/leaflets about its own activities. A single publication was issued: in commemoration of the fiftieth anniversary of the foundation of the institution, containing information on the school's history. This publication was distributed during the anniversary celebration. On the whole, it can be concluded that the institution does not seek to use ATL tools on a regular basis.

Among the digital solutions bordering on ATL and BTL tools, the school's Facebook profile takes the leading role. The page was created in 2012, but it was not used regularly until 2017. It focuses on the presentation of major school 
events (celebrations, various programmes, travel abroad, or the participation of student teams that represent the school in professional competitions); therefore, posts are created on such occasions exclusively. As a rule, dozens of photos are attached to each one of these short posts. The photos raise interest among the students and their parents ('likes'). Only one of the classes has a website, whose structure is simple, and there are no built-in interactive functions. There is no link between the website and the Facebook page. The website of the settlement does not feature any informational material about the school. The institution does not send out any newsletters, and it has no activity on either Twitter or YouTube channels.

Activity is more diversified, however, when it comes to the use of BTL tools. The institution places great emphasis on organizing celebrations and events that take place on an annual basis at which it also involves the population of the settlement as an audience. Such an event of major importance is the celebration of March 15, a national holiday, in which context the person giving his name to the school is also celebrated. Likewise, the senior prom and one or two school sports events are of key importance as well. These festive occasions are not connected with the institution's education activities, their purpose being to strengthen the institution's identity. The institution does not organize recruitment programmes in the settlements of the region. Although there were attempts at organizing open days to promote the activities of the institution, these were ultimately not realized as regular events. Once every year, the school presents its educational offering at a county-level career fair organized for grade schoolers. The student teams of the school take part in professional competitions organized in the region. Information sent by means of e-mail is not an institution-wide procedure - it works only at the level of each class, serving for the occasional dissemination of information between the teacher responsible for a specific class and the parents of the students in that class. School activities aimed at improving its public relations as well as its image-building efforts are reflected in the use of the school's name, the (restrained) use of the national colours in relation to the person giving his name to the school, and frequent verbal reference to the history of the school. The mission, ideology, and organizational philosophy of the school are laid out in strategy papers compiled as official documents, which cannot be traced, however, in the communication channels used by the school. Knowledge related to the school's identity and role is strongly formulated as some sort of internal content in the interviews conducted with the head of the school and the pedagogues, but it does not appear as explicit communication content.

Overall, it can be said that - judging by its operational model - the school has an inward-looking focus, and it is only on an ad-hoc basis, in the context of 
certain representative events, that it makes attempts to demonstrate its identity to regional society. There is virtually no communication on the part of the school targeted at the two most important social groups: parents, and the regional élite. The communication practices of the institution cover a small number of products, are temporary and unidirectional in nature, and do not involve putting forward any messages regularly about either the educational activities or the internal life of the institution. The school is not open to its social environment, stakeholders' opinions do not reach the institution, and there are many other factors in the operation of the school that contribute to its structural isolation from the local and regional society.

\section{CONCLUSIONS}

Our study made use of a technical college operating in a rural micro-region within Harghita County (Romania) to present the results of three analytical procedures that may be associated with the issues concerning the relationship between the institution and micro-regional society. Analytical work was undertaken on the grounds that the school had been having problems fulfilling its role within the region for the past few decades. What constituted clear incentives for our work were those professional analyses carried out in the last couple of decades that advocated the importance of cooperation between the school and the local community (Miller 1995; Flora-Flora 1993). Results obtained from the parents and the regional élites suggest that these groups attach high importance to the present and future role of agriculture in the studied micro-region, and we understand this attitude as a clear signal of strong commitment to supporting secondary agricultural education in the micro-region. In addition, the élites and the parents alike explicitly emphasize the professional role of the school in the region and the importance of developing the institution and the education by also relying on the traditional practices of the area. Results of the school's marketing communication show that the institution positions its mission and activities towards regional actors with limited effectiveness and on an occasional basis; its external communication is accidental and poor; and it takes no account of stakeholders' opinions within the micro-region. Its approach to regional society could be described as structural isolation rather than approximation or cooperation. Consequently, support on the part of the regional élites and the parents remains under-exploited.

The fact that the attitudes of parents and regional élites are not consistent with the school's marketing communication practices may represent a 
barrier to the future of the school in terms of it functioning as a key player in the development of the regional agricultural sector. The positive attitude on the part of the parents and the regional élites suggests essential but not yet exploited potential for the school. Being aware of the above-outlined positive attitudes, it is suggested that redesigning the school's marketing communication practices may be a way of launching the school's regionalscale repositioning process.

\section{REFERENCES}

Bauch, P. A. (2001) School-community partnerships in rural schools: Leadership, renewal, and a sense of place. Peabody Journal of Education. Vol. 76, No. 2., pp. 204-221, DOI: 10.1207/S15327930pje7602_9

Biriescu, S. - C. Babaita (2014) Rural education, an important factor of regional development in the context of local government strategies. Procedia - Social and Behavioral Sciences, Vol. 124, pp. 77-86, DOI: 10.1016/j. sbspro.2014.02.462

Biró, A. Z. - F. Magyar (eds. 2013) Vidék és versenyképesség. Agrárinnovációs helyzetkép a székelyföldi térségben (Countryside and Competitiveness. Agricultural Innovation Situation in the Szeklerland Region). Csíkszereda, RO, Státus

Biró, A. Z. - F. Magyar (eds. 2016) Agrárinnováció - térségi esély. Fiatal gazdák a székelyföldi térségben (Agricultural Innovation - Regional Opportunity. Young Farmers in the Szeklerland Region). Csíkszereda, RO, Státus

Biró, A. Z. - F. Magyar (eds. 2017) A generációváltás esélyei. Agrárvállalkozók innovativ szerepe a székelyföldi térségben (The chances of Generational Change. Innovative Role of Agricultural Entrepreneurs in the Szeklerland Region). Csíkszereda, RO, Státus

Biró, A. Z. - F. Magyar (eds. 2018) Kísérlet vagy modell? Az agrárinnováció, mint székelyföldi fejlesztési paradigma (Experiment or Model? Agricultural Innovation as a Development Paradigm in Szeklerland). Csíkszereda, RO, Státus

Biró, A. Z. - F. Magyar (eds. 2019) Digitális agrárium - székelyföldi innováció. Az agrárium digitalizációjának térségi környezete (Digital Agriculture Innovation in the Szeklerland. The Regional Environment of the Digitization of Agriculture). Csíkszereda, RO, Státus

Burch, P. (2009) Hidden Markets: The New Education Privatization. New York, NY, Routledge 
Fazekas, I. - D. Harsányi (2011) Marketingkommunikáció érthetően (Marketing Communication). Budapest, Szokrátész Külgazdasági Akadémia

Flora, C. B. - J. L. Flora (1993) Entrepreneurial social infrastructure: A necessary ingredient. ANNALS of the American Academy of Political and Social Science, Vol. 529, No. 1., pp. 48-58, https://doi.org/10.1177/0002716293529001005

Fulton, O. (2003) Managerialism in UK Universities: Unstable Hybridity and the Complications of Implementation. In: Amaral, A. - V. L. Meek - I. M. Larsen (eds.): The Higher Education Managerial Revolution? Dordrecht, NL, Kluwer Academic Publishers, pp. 155-178.

Gewirtz, S. - S. S. J. Ball - R. Bowe (1995) Markets, Choice and Equity in Education. Buckingham, UK, Open University Press

Horváth, D. - A. Bauer (2013) Marketingkommunikáció. Stratégia, új média, fogyasztói részvétel. Budapest, Akadémiai Könyvkiadó

Hutflesz, M. (2004) Iskolafejlesztés és marketing (School Development and Marketing). EURÓPAI REGIONÁLIS FEJLESZTÉSI ALAP INTERREG III. A Közösségi Kezdeményezés Program Szlovénia Magyarország - Horvátország Szomszédsági Program ITTKÉSZ-SL-HUCR/05/4012-106/2004/01/HU-44， http://ittkesz.regiofokusz.hu/tananyagok/ iskolamarketing/1.\%20modul\%20tananyag.pdf. [Last access: 0221 2020]

Kotler, P. - K.F.A. Fox (1995) Strategic Marketing for Educational Institutions. (2nd Ed.) Hoboken, NJ, Prentice-Hall Inc.

Laki, Z. - A. Z. Biró (2001) A globalizáció peremén. Kunhegyes térsége és a Csíki-medence az ezredfordulón. Budapest, MTA Politikai Tudományok Intézete.

Lingam, G. I. - N. Lingam - K. Raghuwaiya (2014): Challenges for rural school leaders in a developing context: The case of Solomon Islands. World Academy of Science, Engineering and Technology International Journal of Social, Human Science and Engineering., Vol. 8, No. 2., pp. 1-9, DOI: doi. org/10.5281/zenodo.1090514

Lipman, P. (2011) The New Political Economy of Urban Education: Neoliberalism, Race, and the Right to the City. New York, NY, Routledge

Miller, B. (1995) The Role of Rural Schools in Community Development: Policy Issues and Implications. Program Report. https://files.eric.ed.gov/fulltext/ ED393617.pdf [Last access: 0216 2020]

Muhi, B. (2012) Az iskolamarketing elméleti és gyakorlati kérdései (Theoretical and Practical Issues of School Marketing). http://www.vmtt.org.rs/ mtn2012/348_357_Muhi_ifj_A.pdf [Last access: 01 12 2020]

Olsen, D. D. (2017) Homegrown Rural School Leaders. PhD Thesis, University of Iowa, 2017. https://doi.org/10.17077/etd.st6dgklx, https://ir.uiowa.edu/cgi/ viewcontent.cgi?article $=7067 \&$ context $=$ etd [Last access: 0327 2020] 
Pollitt, C. (2003) The Essential Public Manager. Maidenhead/Philadelphia, US, Open University Press

Santiago, R. A. - A. Magalhães - T. Carvalho (2005) O Surgimento do Managerialismo No Sistema de Ensino Superior Português [The Emergence of Managerialism in Portuguese Higher Education System]. Coimbra, PT, CIPES

Sárosi-Blága, Á. (2018a) Iskola társadalmi elfogadottsága és vidékfejlesztési jelentősége egy kistérségben müködő szakiskola példáján (Social acceptance of schools and their importance for rural development on an example of a vocational school operating in a small rural region). Falu Város Régió Területfejlesztési Szakmai Folyóirat, Vol. 1., pp. 120-123, ISSN 1218-2613

Sárosi-Blága, Á. (2018b) A vezetés mint fejlesztési lehetőség és eszköz vidéki iskolákban (Leadership as an opportunity and tool for development in rural schools). Pro Scientia Ruralis, Vol. 1., pp. 43-51, ISSN 2457-9068

Sousa, S. F. (2013) Families, schools and the image communication in the education market. International Journal about Parents in Education, Vol. 7, No. 2., pp. 177-188, ISSN 1973-3518.

Tomoletiu, A. E. - A. Moraru (2010) Rural education in Romania: Present and perspectives. Procedia - Social and Behavioral Sciences, Vol. 2., pp. 402-406, DOI: 10.1016/j.sbspro.2010.03.034

Wallin, D. C. - P. Newton (2014) Teaching principals in small rural schools: "My cup overfloweth". Alberta Journal of Educational Research, Vol. 60, No. 4., pp. 708-725, DOI: https://doi.org/10.11575/ajer.v60i4.55982

White, S. - J.-A. Reid (2008) Placing teachers? Sustaining rural schooling through place-consciousness in teacher education. Journal of Research in Rural Education, Vol. 23, No. 7., pp. 1-11, ISSN 1551-0670

Woods, P. - C. Bagley - R. Glatter (1998) School Choice and Competition: Markets in the Public Interest? London, UK, Routledge 
